\title{
Guardar un diente, ¿salva una vida?
}

\author{
Does preserving a tooth save a life?
}

\author{
Enrique Grageda Núñez*
}

"La ciencia son hechos; de la misma manera que las casas están hechas de piedras, la ciencia está hecha de hechos; pero un montón de piedras no es una casa y una colección de hechos no es necesariamente ciencia.»

\section{Henri Poincaré}

"Guarda un diente, salva una vida». Los dientes son una fuente abundante de células madre que se pueden preservar y obtener un seguro biológico para el paciente y su familia. ${ }^{1}$ Éste es tan sólo uno de los estandartes que bancos de células madre dentales se han encargado de publicitar sin ética alguna, invirtiendo fuertes cantidades de recursos económicos en medios masivos de comunicación y con conferencias en foros odontológicos por parte de "asesores científicos" patrocinados por estos bancos y dirigidas a las comunidades odontológicas de nuestro país.

Las expectativas producidas después del anuncio del aislamiento de estas células a partir de dientes temporales en el 2003 por el Dr. Shi, quien es profesor del Centro de Biología Craneofacial de la Universidad del Sur de California, ${ }^{2,3}$ no sólo permitieron diversificar la investigación en el medio científico de las células madre embrionarias y del cordón umbilical, que hasta hace algunos años se creía eran las únicas con esta capacidad de diferenciación, sino además han motivado a buscar nuevas aplicaciones terapéuticas que con otro tipo de células madre no era posible conseguir.

Toda esta información está perfectamente expuesta y eficazmente manipulada por los bancos privados de células madre dentales, que mediante su equipo de ventas y asesores científicos se han encargado de promocionar el resguardo de estas células de manera dogmática, sin fundamentación científica y omitiendo los más simples conceptos de biología molecular e ingeniería genética. Estos bancos ofrecen sus servicios a una comunidad odontológica dispuesta a brindar en una época de continuos avances tecnológicos alterna- tivas innovadoras a sus pacientes para prevenir enfermedades o padecimientos futuros; así como a una generación ávida de nuevos tratamientos médicos que consigan curar, preservar o por lo menos mantener la calidad de vida a lo largo de los años.

En la actualidad, a pesar de que estas células de origen mesenquimatoso han demostrado su capacidad de diferenciación a nivel experimental en células nerviosas, musculares, óseas o cardiacas, ${ }^{4}$ nada se encuentra más distante de la realidad en relación a que éstas puedan aplicarse como una alternativa terapéutica real para tratar enfermedades o padecimientos hasta ahora incurables. Resulta fundamental diferenciar entre estudios experimentales in vitro o in vivo en animales, y contar con aplicaciones clínicas reales en humanos como pretenden los bancos hacerlo creer. Para lograr conseguir una aplicación terapéutica con células madre dentales, es necesario entre otras muchas cosas identificar todos los genes involucrados en el proceso de diferenciación de estas células, así como conocer su interacción y expresión una vez que se activan los mismos. De igual manera es necesario aislar y analizar todos los factores de crecimiento y de transcripción involucrados en el proceso de diferenciación de estas células, los que a la fecha se desconocen en su mayoría y que se comportan de forma distinta dependiendo del orden y presencia de uno o varios de estos factores durante su función. ${ }^{5}$ Finalmente es necesario determinar la vía de administración ideal y el mejor medio de proliferación que permita su crecimiento sin alterar las características, calidad y tipo de células en las que se pudieran llegar a diferenciar. ${ }^{6}$

Tratar de explicar las consideraciones anteriores sería como intentar cocinar un pastel sin conocer los

\footnotetext{
* Especialista en Ortodoncia. Maestría en Biología Molecular Craneofacial.
}

Este artículo puede ser consultado en versión completa en http://www.medigraphic.com/facultadodontologiaunam 
ingredientes. Los mismos bancos privados de células madre lo intentan parcialmente y aceptan que no se tendrá mayor información por lo menos en los próximos 10 a 15 años, escudándose en que su función como banco no es ofrecer terapias innovadoras o tratamientos médicos a los pacientes que contratan sus servicios. ${ }^{7}$ A pesar de todos estos factores, justifican su presencia como una alternativa más para aquellas personas interesadas en resguardar y obtener un «seguro biológico» con estas células para una aplicación terapéutica futura y la posible curación de enfermedades como Alzheimer, Parkinson, esclerosis múltiple, enfermedades cardiacas y diabetes, entre muchas otras. ${ }^{1}$

Múltiples estudios de criopreservación de células madre de cordón umbilical han demostrado que su vida máxima es de 10 años y hasta el momento, en las de dientes, de 2 a 3 años. Esto sin tomar en cuenta que el método de criopreservación ideal de las mismas debe ser específico, dependiendo del tipo y cantidad de células a resguardar, ya que hasta ahora se ha demostrado que el mismo método utilizado para criopreservar las células madre de cordón no se puede aplicar al de las células de los dientes, porque éstas pierden muchas de sus características, encontrándose aún en discusión el método ideal para su criopreservación y almacenamiento, con el objetivo de preservarlas a largo plazo sin que pierdan sus características. Finalmente, se han reportado múltiples estudios donde se demuestra un riesgo continuo de contaminación cruzada entre las muestras de diversos pacientes al criopreservarlas. ${ }^{8-11}$

Entonces, ¿por qué tener que pagar a un banco privado por el resguardo de células durante algunos años a pesar de que los padecimientos ya antes mencionados se presentan con mayor frecuencia a partir de la tercera década de la vida?, ¿por qué a pesar de que sabemos que estas células conservan sus características por un periodo muy corto de tiempo, los bancos ofrecen planes financieros para resguardar estas células hasta por 10 o 20 años?

Además, estudios recientes demuestran que los dientes permanentes también ofrecen una posible fuente de células madre a pesar de tener características diferentes a las de los dientes temporales. Sin embargo, es posible manipularlas y conseguir estas células progenitoras a partir de otras células madre o de células convencionales del periodonto y, más aún, obtener células madre de origen mesenquimatoso de otras áreas de nuestro organismo, como el tejido adiposo..$^{12-14}$

En otras palabras, ¿no tendríamos las mismas o inclusive mejores probabilidades de utilizarlas al mantener los dientes en nuestra boca y evitar pagar el resguardo de estas células madre dentales en el banco, permitiendo que la ciencia avance y que no caduque el tiempo de la criopreservación?

La legislación al respecto varía en diferentes partes del mundo; mientras que la FDA (Federal Drug Administration) de los Estados Unidos mantiene una posición ambigua y poco clara, otros han establecido leyes, instituciones y reglamentaciones muy específicas que han permitido regular e informar de forma precisa y adecuada a los odontólogos y pacientes, limitando de forma eficaz a estos bancos privados de células madre dentales. ${ }^{15}$

En México, la Facultad de Odontología de la UNAM ha tomado nuevamente el liderazgo en este tema mediante la promoción de cursos de educación continua sin patrocinios ni intereses comerciales o algún tipo de lucro. Todo esto con el objetivo de difundir ante la comunidad odontológica una visión real de los alcances y limitaciones del uso de estas células para poder informar debidamente a los pacientes.

Hasta ahora no existe una Norma Oficial Mexicana por parte de las autoridades de la Secretaría de Salud que determine con detalle el uso, resguardo, reglamentación, manipulación, propiedad de las mismas y aplicaciones terapéuticas de las células madre de cualquier tipo, incluyendo las dentales, creando un vacío legal en nuestro país, lo cual favorece la desinformación, el oportunismo y el indebido manejo de la información que los bancos de células madre dentales han capitalizado hasta el momento.

Actualmente en México, los bancos de células madre dentales son compañías transnacionales privadas con representantes en nuestro país, que operan con el registro ante la Secretaría de Salud a través de la COFEPRIS, bajo el permiso sanitario de resguardar estas células con fines de «investigación» sin actuar fuera de la ley. De acuerdo a la Ley General de Salud, hasta ahora cualquier terapia o tratamiento médico en seres humanos con estas células madre dentales se encuentran prohibidos por la legislación mexicana, además que realizarlo sería un acto completo de irresponsabilidad, ignorancia y falta de ética profesional, por no existir aún los fundamentos y bases científicas necesarios para realizarlo. ${ }^{16}$

Estoy seguro de que ningún paciente paga una cantidad significativa de dinero con la finalidad de preservar sus células dentales y que se utilicen con fines de investigación. Absolutamente todos tienen la ilusión, esperanza y certeza de utilizarlas en un futuro con algún familiar o con ellos mismos en el caso desafortunado de llegar a necesitarlas.

De acuerdo a la Asociación Americana de Sangre y de Trasplante de Médula Ósea, las probabilidades de que pudiera un paciente utilizar las células de cordón 
umbilical guardadas en un banco privado son de tan sólo un $.001 \%$. Por pura ley de probabilidad es imposible que este porcentaje aumente significativamente con las células madre dentales por lo menos en los próximos años. ${ }^{17}$

Antes de recomendarle a un paciente que "guarde un diente y salve una vida», detengámonos a pensar sobre todas las implicaciones éticas, legales y financieras que involucra hacer uso de estos bancos, y sobre el papel que debemos jugar como odontólogos ante nuestra comunidad con las células madre dentales.

\section{REFERENCIAS}

1. Tríptico publicitario y página web de BioEDEN México. Disponible en: www.bioeden.mx

2. Shi S, Gronthos S. Perivascular niche of postnatal mesenchymal stem cells in human bone marrow and dental pulp. J Bone Miner Res. 2003; 18: 696-704.

3. Miura M, Gronthos S, Zhao M et al. SHED: stem cells from human exfoliated deciduous teeth. Proc Natl Acad Sci USA. 2003; 100: $5807-5812$.

4. Arora $\mathrm{V}$ et al. Banking stem cells from human exfoliated deciduous teeth (SHED): saving for the future. J Clin Pediatr Dent. 2009; 33 (4): 289-294.

5. Bluteau $\mathrm{G}$ et al. Stem cells for tooth engineering. Eur Cell Mater. 2008; 16: 1-9.

6. Yu J et al. Differentiation potential of STRO-1 + dental pulp stem cells changes during cell passaging. BMC Cell Biology. 2010; 11: 32. Disponible en: http://www.biomedcentral.com/1471-2121/11/32

7. Advierten bancos sobre uso a largo plazo. Dudan de almacenar las células dentales. Periódico Reforma. Lunes 8 de abril del 2013; Sección Nacional: 16.
8. Woods E et al. Optimized cryopreservation method for human dental pulp-derived stem cells and their tissues of origin for banking and clinical use. Cryobiology. 2009; 59: 150-157.

9. D'Aquino R et al. Dental pulp stem cells: a promising tool for bone regeneration. Stem Cell Rev. 2008; 4: 21-26.

10. Ying $X$ et al. Ex vivo expansion and pluripotential differentiation of cryopreserved human bone marrow mesenchymal stem cells. J Zhejiang Univ Sci B. 2007; 8 (2): 136-146.

11.Papaccio G, Graziano A, d'Aquino R, Graziano MF, Pirozzi G, Menditti $D$ et al. Long-term cryopreservation of dental pulp stem cells (SBP-DPSCs) and their differentiated osteoblasts: a cell source for tissue repair. J Cell Physiol. 2006; 208 (2): 319-325.

12. Laino $\mathrm{G}$ et al. A new population of human adult dental pulp stem cells: a useful source of living autologous fibrous bone tissue (LAB). J Bone Miner Res. 2005; 20 (8): 1394-1402.

13. Suchanek $J$ et al. Dental pulp stem cells and their characterization. Biomed Pap Med Fac Univ Palacky Olomouc Czech Repub. 2009; 153 (1): 31-36.

14. Huang GT et al. Mesenchymal stem cells derived from dental tissues versus those from other sources. Their biology and role in regenerative medicine. J Dent Res. 2009; 88 (9): 792-806.

15. Thirumala $S$ et al. Clinical grade adult stem cell banking. Organogenesis. 2009; 5 (3): 143-154.

16. Ley General de Salud en materia del control sanitario para la disposición de órganos, tejidos y cadáveres de seres humanos. Art 3. Fracc XVIII., Art 90. Fracc II., Art 313. Fracc I.

17. ASBMT Position statement. Collection and preservation of cord blood for personal use. Biology of blood and marrow transplantation. 2008; 14: 364.

18. Jeong $\mathrm{Y}$ et al. Nuclear receptor regulation of stemness and stem cell differentiation. Exp Mol Med. 2009; 41 (8): 525-537.

Dirección para correspondencia:

Enrique Grageda Núñez

E-mail: enriquegrageda@ hotmail.com 